increase of 3.5 per cent a year in GNP per head in the developing world-not nearly enough to make a substantial difference to the present unequal distribution of prosperity. If the world is to be within sight of an equitable balance between rich and poor countries by the end of the century, the real growth of prosperity in the developing world should be the equivalent of more like 10 per cent than 6 per cent a year, and at the beginning at least, this will have to be financed by increased production in the industrialized nations of the world. In short, there is a danger that too much alarm about the distant but speculative limits to economic growth may serve, whatever its authors intend, as an intolerable brake on the process of social development in the countries where the need is greatest.

\section{European Technology}

ON the face of things, the conference being held this week at Venice by the Commission of the European Communities is unlikely to do as much as its sponsors hope for the fuller exploitation of technology in Europe. A part of the trouble is that the conference will mix together discussions of the ways in which technology might be more fully exploited with discussions of less tangible questions, regional policy, one of the Communities' perennial hot potatoes, and the still more fashionable preoccupations with multinational enterprises-are they benefits or millstones round the neck of the European enterprise? To be sure, the organizers are right in thinking, as apparently they do, that it is not feasible to divorce technological development from a consideration of the structure of industry, but on this occasion they have put the cart before the horse and have decided to spend more time than is necessary at this stage on longterm problems which are essentially political in character and too little on the structural questions which are of practical and immediate importance. It is all very well, for example, to brood about the policy for regional development which the Communities should pursue, and Mr Derek Ezra, the chairman of the National Coal Board, will no doubt be eloquent on the subject. Yet it remains an open question whether at this stage the Communities should commit themselves to a policy that will inhibit the further growth of industry in parts of Europe already industrialized for the sake of encouraging industry to move to regions which are still comparatively rural. To be sure, there are important social problems to be dealt with, but there is at least a chance that the Communities' concern with environmental matters (also on the agenda at Venice) might be more adequately met by concentration, not dispersion.

The missing elements in the conference agenda suggest that a valuable opportunity is being lost. So far, the Communities have sought to increase the pace of technological development by devices such as the removal of technical barriers to trade and the introduction of a European patent system and, indeed, there is no doubt that the creation of the Communities, which allow for free trade and the free movement of capital (in due course), will powerfully stimulate the growth of technologically founded companies of all kinds. Yet under present circumstances, there are no European institutions for helping to remove the technological chauvinism by means of which European countries set out on needless and wasteful competition with each other. The competitive development of fast reactors in Britain, France, Germany and even Italy is a continuing scandal, unlikely to be tackled at Venice. Is it not time, the sad example of Euratom notwithstanding, that Brusse's paid some attention to this question? And is it not high time that steps were taken to channel public investment in the several aircraft industries of Europe into coordinated programmes? The cooperative programmes on computer development, the most tangible products of the Aigrain working groups of 1969 , have been a disappointment. And nothing much has yet been done to make the work of large government research establishments-the defence research establishments in Britain, for example-more widely available not merely to European governments but to industrial companies. It would have been valuable if the conference at Venice could have tackled subjects like these. Its preoccupation with the more distant problems seems likely to give it an air of unreality.

\section{Concorde Economics}

THE British and French governments have only themselves to thank for the mess they have got themselves into with their plan to develop a supersonic air transport. Last week, Mr John Davies (for Britain) and Mr Jean Chamant (for France) agreed that work should begin in earnest on a further six aircraft, bringing the total to sixteen. In the same breath, they agreed to a further increase of the development budget for this risky venture, which is now quickly approaching $£ 1,000$ million. At the same time, like other entrepreneurs before them, the two governments are anxiously confronting the awkward question of whether their new products will be commercially viable. The chances are that in the next few weeks, Air France and British Overseas Airways Corporation will be persuaded by the two governments to confirm at least some of their tentative orders for the Concorde, but this is not a seller's market. Nobody will be surprised if the two national airlines are able to buy their Concordes at bargain prices. If the airlines are sensible, they will not quibble much about the initial cost, likely to work out at a little more than $£ 20$ million an aircraft, but will ask for a continuing subsidy on the cost of operation, if only on the grounds that by putting these novel aircraft into service before there is an economically compelling case for doing so, they are helping the manufacturers to demonstrate (if that is possible) that supersonic aircraft are indeed an economic benefit.

That other airlines should lag behind is entirely understandable. After all, potential customers have at present no means of knowing where supersonic aircraft will be allowed to operate. It will be a long time before the American authorities will be prepared seriously to consider applications for permission to fly supersonically over the United States and Canada-questions of critical importance to airlines in North America. And although there is scope for using Concordes on the transatlantic and transpacific routes as well as between Europe and Africa, it remains something of a puzzle to know whether journeys between, say, Frankfurt and New York will be 